\title{
Syntactical Repetition on Selected Poems of Maya Angelou
}

\author{
anna riana suryanti tambunan ${ }^{1}$, Maria Silaban ${ }^{2}$, Rika Haloho ${ }^{3}$, Priskila \\ NAINGGOLAN $^{4}$, OLIVIA RIZKI ${ }^{5}$, RAHMAT EKO ${ }^{6}$, RYO TAUHID ${ }^{7}$ \\ ${ }^{123567}$ UNIVERSITAS NEGERI MEDAN
}

\begin{abstract}
The aim of this research is to find out the syntactical repetition on selected poems by Maya Angelou namely Still I Rise, Caged Birds, Alone and Woman Work. The technique of collecting the data was to download the selected poems. The data were analyzed and found four repetition that he said. The repetition is Anaphora, Epiphora, Framing, and Anadiplosis. Our research found that the repetition used to stress the author's goals on her poem. It can be make people remember her intention in her poem.
\end{abstract}

Keywords: Stylistic, repetition, poem

\section{INTRODUCTION}

Humans have different think, different ways, reasons and also style to pouring their thoughts on their literary work. The style of literary work makes the work more wonderful and interesting. Therefore it is interesting to research on syntactical repetition especially in poems.

Generally, style is defined as the way in which a given person uses language in a given context for a given purpose (Leech and Short, 1981). In this case, the writer purposes will decide the style of the text, and usually it is studied through the field of stylistics. As stated by Leech and Short that stylistics is simply defined as the linguistic study of style (1981: 13). Repetition is part of stylistic devices lesson. Syntactical repetition is one of stylistic devices that we can found in many literary works. This stylistic device is about the repetition of word or phrase, clause or sentence.

Maya Angelou, originally a dancer, eventually turned her hand to poetry and writing and gained great success as a popular, strong voice for the oppressed and vulnerable people of the world. She became a well-known civil rights pioneer. Her work continues to inspire those who want to live in a world where equality, justice, and transparency apply to all, regardless of skin, creed or sexual orientation.

Maya Angelou's "Alone" is a poem that deals with togetherness by placing emphasis on being alone; quite an irony. It is a lyrical "thinking out loud", a reflection on what it is to be a human and 'out here' in the big wide world. On the one hand, it is a personal epiphany - an individual, the speaker, has decided that, for the good of her soul, she cannot be alone. To make 
it, she'll need to work with others. And on the other, it is a calling to society to come together as one.

Still I Rise is a powerful, empowering poem all about the struggle to overcome prejudice and injustice. It is one of Maya Angelou's most popular poems. When read by those who understand the meaning of repeated wrong doing, the poem becomes a kind of anthem, a beacon of hope for the oppressed and downtrodden. It is a reminder of the abuse of power by those who sit in government, the judiciary, in the military and in the police force. For members of the public, for society, it sends out the clear, repeated message of hope. No matter the circumstances, there must always be hope to cling on to.

Maya Angelou was famous during her lifetime for works that could represent her own identity with power and distinction, and Woman Work is surely one of the best examples of the style. Whether or not the "Woman" is meant to be an aspect of Angelou herself is unclear, but the complexity of emotion used to build up the poem makes it a very clearly very personal work for the late author, one that is an excellent example of her powerful style and insightful prose as well.

'Caged Bird' is a poem written by Maya Angelou which considers the conditions of the 'free bird' and the 'caged bird'. Actually this contrast between the birds enables her to express her own emotions about freedom and isolation. The poem is quite symbolic so there are various hidden messages she tries to convey about her feelings mostly indirectly.

Repetition is one of the syntactic stylistic devices which is used to show the state of the mind of the speaker when he is under the stress of strong emotion. It tends to give a logical emphasis which is necessary to fix the attention of the reader on the key word of the utterance. Galperin (1977) classifies repetition according to compositional pattern. He subcategorizes repetition into four main types namely; anaphora, epiphora, framing and anadiplosis.

Based on the explanation above, the purpose of this research is to find out types and aims of syntactical repetition stylistic devices on poems Maya Angelou. By using stylistic devices, the poems Maya Angelou become interesting and attractive. They create some effects in poems so the readers would feel enjoyable reading poems and also it is helpful for them to catch ideas or messages from the writer of the poems.

It is a well-known fact that there exist various ways of expressing people's attitude towards another person, any kind of thing or this or that phenomena; there are different variants of expressing similar, though not absolutely identical ideas. It is stylistics that deals with all variants of linguistic expressions and the sub-systems making up the general system of language. Stylistic devices play the greatest role in the analysis of any kind of literary text. Among other figures of speech, repetition is one of the widely used syntactic stylistic devices 
(Nino\&Tama, 2013).

Repetition is a figure of speech that shows the logical emphasis that is necessary to attract a reader's attention on the key-word or a key-phrase of the text. It implies repeating sounds, words, expressions and clauses in a certain succession or even with no particular placement of the words, in order to provide emphasis. There is no restriction in using repetition but too much repetition can be dull and even spoil its stylistic effect. (Nino \& Tamar, 2013).

Refrain is purely a poetic device, and the most important function that a refrain may serve in poetry is to lay emphasis and create rhythm. When a line or phrase recurs in a poem, or a piece of literature, it becomes noticeable to the readers. By using refrain, poets can make their ideas memorable, and draw the attention of readers toward a certain idea. This is done by using a single line recurrently throughout a poetic work, allowing readers to take a pause each time they come upon such repetition.

"I'll rise" helps affirm the ideas of moving forward and being successful despite what society may think of you. By writing this, at the end of the stanzas, Angelou always brings the poem back to the idea of rising up and moving forward to a positive future. This grounds the meaning of the poem in a single purpose: the positive affirmation that no matter the oppression, prejudice, hate, etc. the speaker (as representative of women and African Americans)will still succeed. (Stuart Henderson, 2013)"

According to the book "An Introduction to English Stylistic" by Tartu state University, here we conclude the definition of each repetition.

1. Anaphora ; repeat the word or phrase at the beginning of the line

2. Epiphora ; repeat the word or phrase in the middle on line

3. Anadiplosis ; repeat the word or phrase at the last line

4. Framing ; repeat the word or phrase in the beginning and the last line

5. Syntactical Tautology; repeat the word with the synonym. It can be the characteristic

\section{METHODOLOGY}

\subsection{Technique Collecting Data}

In this research, we use the internet to searching poems of Maya Angelou. We analyze every poems and we take only four poes that using different syntactical Repetition and also the theory and the previous research that we needed.

\subsection{Technique Analysing Data}

To analyze the data, we have learn about this study before, so we divide each poem for every members of group to analyze. We used book "An Introduction to English Stylistic" by Tartu State University as our main references and there are also some previous article to help us. We analyze every stanza and find the syntactical repetition there. 


\section{FINDINGS \& DISCUSSIONS}

We have found repetition devices, that is; Anaphora, Epiphora, Anadiplosis, Framing and Syntactic Tautology on Maya Angelou Poems.

\subsection{Still I Rise}

\subsubsection{Anaphora}

Stanza 1, lines 1 and 3 ;

You maywrite me down in history

With your bitter, twisted lies,

You may tread me in the very dirt

But still, like dust, I'll rise.

Stanza 3,lines 1 and 3;

Just like moons and like suns,

With the certainty of tides

Just like hopes springing high,

Still I'll rise.

Stanza 6, lines 1,2, and 3;

You may shoot me with your words,

You may cut me with your eyes,

You may kill me with your hatefulness,

But still, like air, I'll rise.

Stanza 7, lines 1 and 2 ;

Does my sexiness upset you?

Does it come as a surprise

That I dance like I've got diamonds

At the meeting of my thighs?

Stanza 8, lines 2 and 4 ;

Out of the huts of history's shame

I rise

Up from a past that's rooted in pain

I rise

I'm a black ocean, leaping and wide 
Welling and swelling I bear in the tide

Stanza 9, lines 2,4,7,8,9;

Leaving behind nights of terror and fear

I rise

Into a daybreak that's wondrously clear

I rise

Bringing the gifts that my ancestors gave,

I am the dream and the hope of the slave.

I rise

I rise

I rise.

\subsection{Know Why The Caged Bird Sings}

\subsubsection{Anaphora}

Stanza 1, line 2,3,4;

The free bird leaps on the back of the wind andfloats downstream and dips his wing and dares to claim the sky.

Stanza 4, line 2,3,4 ;

The free bir thinks of another breeze and the trade winds soft through the sighing trees and the fat worms waiting on a dawn bright lawn and he names the sky his own

\section{Stanza 5, line 2,3}

But a chaged bird stands on the grave of dreams hisshadow shouts on a nightmare scream his wings are clipped and his feet are tied so he opens his throat to sing

\subsubsection{Epiphora}

Stanza 2 lines 3 and 4 ; 
But a bird that stalks down his narrow cage can seldom see through his bars of rage his wings are clipped and his feet are tied so he opens his throat to sing

\subsection{Alone}

\subsubsection{Anaphora}

Stanza 3 lines 3,4,5;

There are some millionaires

With money they can't use

Their wives run round like banshees

Their children sing the blues

They've got expensive doctors

\subsubsection{Anadiplosis}

Stanza 1 line 8,9;

Lying, thinking

Last night

How to find my soul a home

Where water is not thirsty

And bread loaf is not stone

I came up with one thing

And I don't believe I'm wrong

That nobody

But nobody

Can make it out here alone

\subsubsection{Framing}

Stanza 2 line 1 and 2;

Alone, all alone

Nobody, but nobody

Can make it out here alone. 


\subsection{Woman Work}

\subsubsection{Anaphora}

Stanza 1 lines 2,3,4 and 10,11;

I've got the children to tend

The clothes to mend

The floor to mop

The food to shop

Then the chicken to fry

The baby to dry

I got company to feed

The garden to weed

I; ve got shirts to press

The tots to dress

The cane to be cut

I gotta clean up this hut

The see about the sick

And the cotton to pick

\subsubsection{Framing}

Stanza 2 lines 2 ;

Shine on me, sunshine

Rain on me, rain

Fall softly, dewdrops

And cool my brow again.

\subsubsection{Syntactical Devices}

Stanza 4 Line 3;

Fall gently, snowflakes

Cover me with white

Cold icy kisses and

Let me rest tonight

As weknow, Repetition is a literary device that repeats the same words or phrases to make an idea clearer and more memorable.Fromthatresult, weknowthat in thepoem "Still I Rise", thereisananaphora, An Anaphoraisrepetition of a word or expression at the beginning of 
successive phrases, clauses, sentences, or verses especially for rhetorical or poetic effect.

And for the second poem "Caged Bird", there are anaphora and epiphora. What the difference between anaphora and epiphora? The definition of epiphora is opposite that of anaphora, which is the repetition of a word or phrase at the beginning of successive clauses or sentences. When epiphora and anaphora are used together (i.e., words are repeated at the beginning of successive phrases and different words are repeated at the end of the same phrases), the literary device is called symploce.

At the third poem "Alone", there are anaphora, anadiplosis and framing. Framing is a rhetorical term for the repetition of the last word or phrase of one line or clause to begin the next. Also known as duplicatio, reduplication and redouble.Anadiplosis often leads to climax (see gradatio). Note that a chiasmus includes anadiplosis, but not every anadiplosis reverses itself in the manner of a chiasmus.

The last poem "WomanWork", there are anaphora, framingandsyntacticaldevices. Based on the previous study,we browse the article that related to our Topic which is the Stylistics repetition in Maya Angelou's Poem,"'Still in rise"..In 'The meaning of repetition' Part is ...I'll rise" helps affirm the ideas of moving forward and being successful despite what society may think of you. By writing this at the end of the stanzas Angelou always brings the poem back to the idea of rising up and moving forward to a positive future. This grounds the meaning of the poem in a single purpose: the positive affirmation that no matter the oppression, prejudice,hate, etc. the speaker (as representative of women and African Americans) will still succeed. (Stuart Henderson, 2013)

\section{CONCLUSIONS AND SUGGESTIONS}

Repetition is one of the syntactic stylistic devices which is used to show the state of the mind of the speaker when he is under the stress of strong emotion. It tends to give a logical emphasis which is necessary to fix the attention of the reader on the key word of the utterance.

Anaphora is repetition in the beginning of the line. Epiphora is repeat the word in the middle. Anadiplosis repeat the word in last line. Framing able to repeat in the beginning and in the last. And syntactic Tautology is repetition of word with the synonym.

Maya Angelou on her poems often used the syntactical repetition. It can be a beautiful tone when some on read it. There is also the stress and deep feeling. Inside her poem, anaphora is the most found repetitions. There is also epiphora, anadiplosis, framing and Syntactical Tautology.

As we know, Repetition is a literary device that repeats the same words or phrases to make an idea clearer and more memorable.This research shows that one of the reason why Maya Angelou is consider as the greatest Poet is the repetation of the word that she use 
everytime she makes the poem.Anaphora'srepetation style is probably her favourite one.

\section{REFERENCES}

Anne, M, K (2013). The power of repetition, An Analysis of Repetition Patterns in The Hothouse and The Caretaker by Harold Pinter. The University of Oslo

Leech,G.N. (1981). A Linguistic Guide to English Poetry. London: Longman

Lehtsalu, U (1973). An Introduction to English Stylistics. Tartu State University https://www.merriam-webster.com/dictionary/anaphora

http://www.literarydevices.com/epiphora/

Nino,K \& Tamar,M. (2013). Stylistic Repetition, Its Peculiarities and Types in Modern English. European Scientific Journal, pp. 1-8

Turner, G.W. (1997). Stylistics. Harmondsworth. Harmondsworth : Penguin Book 